\title{
PENGEMBANGAN MEDIA PEMBELAJARAN BAHASA INDONESIA BERBASIS MACROMEDIA FLASH PROFFESIONAL 8 KELAS V SD SWASTA NAMIRA
}

\author{
Indra Yasinta Oktavia marpaung ${ }^{1}$, Sahat Siagian ${ }^{2}$ \\ Teknologi Pendidikan Pasca Sarjana Universitas Negeri Medan \\ Indra_yasinta@yahoo.com ${ }^{1}$
}

\begin{abstract}
Abstrak: Penelitian dan pengembangan ini bertujuan untuk: (1) menghasilkan media yang layak digunakan pada pembelajaran bahasa Indonesia berbasis Macromedia Flash Professional 8 materi menulis surat untuk siswa kelas V SD Swasta Namira Medan, (2) mengetahui keefektifan pengembangan media pembelajaran berbasis Macromedia Flash Professional 8 mata pelajaran bahasa Indonesia pada materi menulis surat untuk siswa kelas V SD Swasta Namira Medan. Jenis penelitian ini adalah penelitian pengembangan yang menggunakan model pengembangan produk Borg dan Gall yang dipadu dengan model pengembangan Dick and Carey. Hasil penelitian menunjukkan: (1) uji ahli materi mata pelajaran bahasa Indonesia berada pada kualifikasi sangat baik, (2) uji ahli desain pembelajaran berada pada kualifikasi sangat baik, (3) uji ahli ahli media/desain grafis pembelajaran berada pada kualifikasi sangat baik, (4) uji coba perorangan berada pada kualifikasi sangat baik, uji coba kelompokberada pada kualifikasi sangat baik, uji coba lapangan berada pada kualifikasi sangat baik. Produk akhir dari pengembangan ini dilanjutkan dengan uji keefektifan. Data ini membuktikan bahwa penggunaan media pembelajaran interaktif menulis surat lebih efektif dalam meningkatkan hasil belajar siswa dari pada tanpa menggunakan media pembelajaran interaktif.
\end{abstract}

Kata Kunci: media pembelajaran bahasa Indonesia, berbasis macromedia flash professional

\begin{abstract}
The research and development is aimed at: (1) produce a decent media used in learning Indonesian-based Macromedia Flash Professional 8 material to write a letter to fifth grade students of private primary schools Namira Medan, (2) determine the effectiveness of the development of media-based learning Macromedia Flash Professional 8 subjects Indonesian on material written to fifth grade students of private primary schools Namira Medan. This type of research is the development of research that uses models Borg and Gall product development combined with Dick and Carey model of development. The results showed: (1) the test subject matter experts subjects Indonesian are in excellent qualifications, (2) test expert instructional design that are in excellent qualifications, (3) expert test expert media / graphic design of learning that are in excellent qualifications, (4) the individual testing are in excellent qualifications, testing kelompokberada the excellent qualifications, field trials are in excellent qualifications. The end product of this development continued with test of effectiveness. These data prove that the use of interactive learning media wrote more effective in improving student learning outcomes than without the use of interactive learning media.
\end{abstract}

Keywords: learning Indonesian media, based macromedia flash professional

\section{PENDAHULUAN}

Mata pelajaran Bahasa Indonesia adalah satu mata pelajaran wajib yang ada di Sekolah Dasar sesuai dengan kurikulum yang diterapkan di Indonesia. Menulis surat juga adalah salah satu materi yang dipelajari dalam kurikulum tersebut. Namun, dalam penyelenggaraan pembelajaran bahasa Indonesia dengan materi menulis surat di SD Namira banyak kendala-kendala yang dihadapi oleh guru antara lain : (1) alat bantu mengajar yang masih kurang, (2) materi/bahan ajar yang masih sulit diperoleh di perpustakaan, (3) aktivitas siswa yang masih rendah dalam pembelajaran, (4) siswa tidak/kurang kreatif dan inovatif dalam pengerjaan tugas (praktik), (5) hasil belajar (nilai mata pelajaran) berupa tugas/praktek atau latihan pada umumnya masih rendah, (6) siswa sering mengabaikan pelajaran bahasa Indonesia karena hanya fokus pada 
pelajaran eksakta dan muatan lokal (bahasa Inggris) yang dianggap lebih sulit.

Media pembelajaran merupakan wahana dan penyampaian informasi atau pesan pembelajaran kepada siswa. Dengan adanya media pada proses belajar mengajar diharapkan dapat membantu guru untuk meningkatkan prestasi belajar siswa. Menurut Hamalik (1984:12), media pendidikan adalah alat, metode dan teknik yang digunakan untuk lebih mengefektifkan komunikasi dan interaksi antara guru dan siswa dalam proses pendidikan dan pengajaran di sekolah.

Media pembelajaran merupakan seperangkat alat bantu atau pelengkap yang digunakan oleh guru atau pendidik dalam rangka berkomunikasi dengan siswa atau peserta didik. Materi yang dikemas melalui program media, akan lebih jelas, lengkap, dan menarik bagi siswa. Media pembelajaran juga mampu menyajikan materi yang dapat membangkitkan rasa keingintahuan siswa, merangsang siswa untuk bereaksi secara fisik dan emosional (Widyastuti \& Nurhidayati, 2010:13).

Macromedia Flash Professional 8 merupakan aplikasi yang digunakan untuk melakukan desain dan membangun perangkat presentasi, publikasi, atau aplikasi lainnya yang membutuhkan ketersediaan sarana interaksi dengan penggunanya. Macromedia Flash Professional 8 terdiri dari teks, gambar, animasi sederhana, video atau efek-efek khusus lainnya. Kelebihan Macromedia Flash Professional 8 sebagai sarana pengembangan materi menulis surat adalah memungkinkan munculnya media pembelajaran, sehingga proses belajar mengajar menjadi terarah dan lebih menarik, sehingga dapat membangun motivasi siswa dan membuat materi yang sulit menjadi mudah diserap. Pengguna dalam hal ini siswa diharapkan akan lebih tertarik dengan adanya media berbasis Macromedia Flash Professional 8 karena media ini memiliki gambar-gambar, teks dan animasi yang full color dan tentu saja dapat menarik perhatian mereka sehingga pembelajaran tidak akan monoton. Pengguna juga akan lebih semangat mengerjakan latihan-latihan atau tugas-tugas yang diberikan guru.

Menurut Snelbecker dalam Almi Afrika (2003:13), ciri-ciri tingkah laku yang diperoleh dari hasil belajar adalah: a) terbentuknya tingkah laku berupa kemampuan aktual maupun potensial, b) kemampuan baru itu berlaku dalam waktu yang relative lama, dan c) bahwa kemampuan baru ini diperoleh dari hasil usaha. Usaha untuk memperoleh kemampuan baru itu diperoleh lewat usaha belajar. Berarti bahwa perubahan tingkah laku dapat disebut sebagai hasil belajar yang diperoleh sebagai hasil usaha belajar untuk dimanfaatkan dalam kehidupan sehari-hari, dan hasil belajar siswa baik berupa perubahan pengetahuan, keterampilan, dan sikap, sangat tergantung pada bagaimana individu berinteraksi dengan lingkungannya termasuk guru.

Bahasa Indonesia dari segi fungsinya mempunyai arti yang sangat majemuk, antara lain, sebagai bahasa persatuan, sebagai bahasa pendidikan, sebagai alat komunikasi resmi, sebagai bahasa sosial, dan sebagai bahasa pertama bagi sebagian besar warga negara Indonesia. Nurhadi (2004:13) mengemukakan tujuan pembelajaran bahasa Indonesia adalah untuk: (1) melatih cara berpikir dan bernalar dalam menarik kesimpulan, misalnya melalui kegiatan penyelidikan, eksplorasi, eksperimen, menunjukkan kesamaan, perbedaan, konsistensi, dan inkonsistensi, (2) mengembangkan aktivitas kreatif yang melibatkan imajinasi, intuisi dan penemuan dengan mengembangkan pemikiran divergen, orisinil, rasa ingin tahu, membuat prediksi dan dugaan, serta mencoba-coba, mengembangkan kemampuan memecahkan masalah, dan (4) mengembangkan kemampuan menyampaikan informasi atau mengkomunikasian gagasan anatara lain melalui pembicaraan lisan, catatan grafik, peta, diagram dalam menjelaskan gagasan.

Menurut Reigeluth (1983) hasil pembelajaran harus memiliki efektivitas, efisiensi dan daya tarik. Efektifitas diukur dari tingkat pencapaian hasil belajar yang diperoleh oleh peserta didik, baik secara kualitas maupun kuantitas. Secara kualitas belajar menunjukkan kebermaknaan isi bahasa yang dipelajari dalam kehidupan sehari-hari, sedangkan kuantitas menunjukkan jumlah variasi hasil belajar yang dapat dicapai oleh siswa. Efisiensi diukur berdasarkan waktu yang dibutuhkan siswa untuk belajar, dalam arti semakin sedikit waktu yang dibutuhkan siswa untuk memahami isi materi pelajaran, maka semakin efisien hasil belajar yang diperoleh. Sedangkan daya tarik diukur dari ada tidaknya kecenderungan siswa termotivasi untuk belajar lebih lanjut dalam arti mengembangkan wawasan berdasarkan hasil belajar yang telah diperoleh. 
Hasil belajar menurut Bloom dalam Nana Sudjana (2009:22-23) menyatakan, hasil belajar dibagi dalam tiga kawasan yaitu kognitif, afektif, dan psikomotor. Kawasan kognitif terdiri dari enam jenis perilaku yaitu: (1) ingatan, mencakup kemampuan mengingat tentang hal yang teah dipelajari dan tersimpan dalam ingatan, pengetahuan tersebut mencakup kemampuan fakta, pengetahuan konsep, pengetahuan prosedur, dan pengetahuan metakognitif, (2) pemahaman, mencakup kemampuan menangkap arti dan makna dari pesan, pembicaraan, tulisan dan grafik, berkaitan dengan pengetahuan fakta dan pengetahuan konsep, (3) penerapan, mencakup kemampuan menerapkan atau menggunakan prosedur untuk mengahadpi situasi yang baru, berkaitan dengan pengetahuan konsep, (5) evaluasi, mencakup kemampuan membentuk pendapat tentang beberapa hal berdasarkan kriteria dan standar teretntu, berkaitan dengan pengetahuan prosedural dan pengetahuan metakognitif, dan (6) kreativitas, mencakup kemampuan menggabungkan beberapa bagian menjadi suatu bentuk yang koheren atau berfungsi secara menyeluruh, mengorganisaikan bagian-bagian menjadi sebuah pola atau struktur yang baru, berkaitan dengan pengetahuan konsep.

Romizowski dalam Mulyono (2008:38) menyatakan bahwa hasil belajar diperoleh dalam bentuk pengetahuan dan keterampilan. Pengetahuan dikelompokkan pada empat kategori yaitu, (1) fakta, merupakan pengetahuan tentang objek, peristiwa atau manusia, (2) konsep, merupakan pengetahuan tentang seperangkat objek kongkrit atau definisi, (3) prosedur, merupkan pengetahuan tentang tindakan demi tindakan yang bersifat linear dalam mencapai suatu tujuan, dan (4) prinsip, merupakan pernyataan mengenai hubungan dari dua konsep atau lebih. Sedangkan hasil belajar dalam bentuk keterampilan juga dikelompokkan dalam empat kategori, yaitu, (1) keterampilan kognitif, merupakan keterampilan seseorang dalam menggunakan pikiran untuk mengambil keputusan atau memecahkan masalah, (2) akting, yaitu keterampilan fisik atau teknik seperti olahraga atau terampil dalam mengerjakan sesuatu, (3) reaksi, merupakan keterampilan bereaksi terhadap suatu situasi dalam arti nilai-nilai emosi dan perasaan dengan orang lain untuk mencapai
Dalam pembelajaran menulis, kegiatan menulis dilakukan secara terpadu dengan memanfaatkan atau menghubungkannya dengan tiga keterampilan lainnya dengan cara beraneka ragam. Dalam memperoleh keterampilan berbahasa, biasanya kita melalui suatu hubungan yang teratur: mula-mula pada masa kecil kita belajar menyimak bahasa kemudian berbicara, sesudah itu kita belajar membaca dan menulis. Keempat keterampilan tersebut merupakan satu kesatuan yang merupakan catur tunggal (Tarigan, 2008:1).

Menulis adalah proses mengungkapkan, mencurahkan atau menuangkan informasi atau berita berupa pikiran, perasaan, kemauan, dengan menggunakan wacana tulis dan berdasarkan pada tatanan serta kaidah bahasa yang berlaku. Senada dengan pendapat Tarigan (1983), Semi (1993:47) mengemukakan bahwa menulis merupakan keterampilan dengan menggunakan bahasa tulis untuk mengungkapkan ide, pikiran, atau perasaan kepada orang lain sehingga diperlukan keterampilan untuk menggunakan aspek berbahasa. Mata pelajaran bahasa Indonesia yang dipelajari di SD Kelas V berdasarkan Kurikulum Tingkat Satuan Pendidikan meliputi aspek mendengarkan, berbicara, membaca dan menulis. Dalam penelitian ini, materi bahasa Indonesia yang dipelajari yaitu aspek menulis dibatasi pada menulis buku harian, menulis surat pribadi, menulis teks pengumuman.

Media adalah bentuk jamak dari medium yang berasal dari bahasa latin medius yang berarti tengah. Dalam bahasa Indonesia kata medium diartikan sebagai 'antara' atau 'sedang' (Latuheru, 1988:14). Pengertian media pembelajaran menurut Latuheru (1988: 14), media pembelajaran adalah semua alat (bantu) atau benda yang digunakan untuk kegiatan belajar mengajar, dengan maksud menyampaikan pesan (informasi) pembelajaran dari sumber (guru maupun sumber lain) kepada penerima (dalam hal ini anak didik atau warga belajar).

Selanjutnya Schramm (dalam Putri, 2011: 20), media pembelajaran adalah teknologi pembawa pesan yang dapat dimanfaatkan untuk keperluan pembelajaran. Jadi media pembelajaran adalah alat bantu yang dapat digunakan untuk pembelajaran. Berdasarkan beberapa pendapat di atas, dapat disimpulkan pengertian media pembelajaran sebagai alat bantu mengajar untuk menyampaikan materi agar pesan lebih mudah diterima dan 
menjadikan siswa lebih termotivasi dan aktif. Sudrajat (dalam Putri, 2011: 20) mengemukakan fungsi media diantaranya yaitu:

a. media pembelajaran dapat mengatasi keterbatasan pengalaman yang dimiliki oleh para siswa

b. media pembelajaran dapat melampaui batasan ruang kelas

c. media pembelajaran memungkinkan adanya interaksi langsung antara siswa dengan lingkungan

d. media menghasilkan keseragaman pengamatan

e. media dapat menanamkan konsep dasar yang benar, kongkrit, dan realistis

f. media membangkitkan motivasi dan merangsang anak untuk belajar

g. media memberikan pengalaman yang integral/menyeluruh dari yang kongkrit sampai dengan abstrak.

Fungsi media yang dipaparkan oleh

Sudrajat tersebut dapat disimpulkan bahwa media pembelajaran berfungsi untuk membantu mengatasi hambatan yang terjadi saat pembelajaran didalam kelas. Hamalik (dalam Arsyad, 2002:15), mengemukakan bahwa pemakaian media pengajaran dalam proses belajar mengajar dapat membangkitkan keinginan dan minat yang baru, membangkitkan motivasi dan rangsangan kegiatan belajar, dan bahkan membawa pengaruh-pengaruh psikologis terhadap siswa. Penggunaan media pembelajaran pada tahap orientasi pembelajaran akan sangat membantu keefektifan proses pembalajaran dan penyampaian pesan dan isi pelajaran pada saat itu. Di samping membangkitkan motivasi dan minat siswa, media pembelajaran juga dapat membantu siswa meningkatkan pemahaman, menyajikan data dengan menarik dan terpercaya, memudahkan penafsiran data dan memadatkan informasi. Paparan fungsi media pengajaran Hamalik di atas menekankan bahwa penggunaan media pembelajaran dalam kegiatan belajar mengajar dapat meningkatkan motivasi dan keinginan belajar siswa serta siswa dapat tertarik dan lebih mudah memahami materi yang disampaikan. Derek Rowntree (dalam Rohani, 1997: 7-8) memaparkan media pembelajaran berfungsi membangkitkan motivasi belajar, mengulang apa yang telah dipelajari, menyediakan stimulus belajar, mengaktifkan respon peserta didik, memberikan balikan dengan segera dan menggalakkan latihan yang serasi.
Pendapat Derek Rowntree di atas tentang fungsi media pembelajaran dapat diketahui bahwa media pembelajaran memiliki fungsi untuk meningkatkan keinginan dan memberikan rangsangan kepada siswa untuk belajar. Media pengajaran, menurut Kemp dan Dayton (dalam Arsyad, 2002: 20-21) dapat memenuhi tiga fungsi utama apabila media itu digunakan untuk perorangan, kelompok atau kelompok pendengar yang besar jumlahnya, yaitu: a) memotivasi minat dan tindakan adalah melahirkan minat dan merangsang para siswa atau pendengar untuk bertindak. b) menyajikan informasi berfungsi sebagai pengantar ringkasan laporan, atau pengetahuan latar belakang. c) memberi instruksi dimana informasi yang terdapat dalam bentuk atau mental maupun dalam bentuk aktivitas yang nyata sehingga pembelajaran dapat terjadi.

Pendapat Kemp dan Dayton (dalam Arsyad, 2002: 20-21) tentang fungsi media pengajaran menekankan bahwa media pengajaran dapat memberikan motivasi dan merangsang siswa untuk belajar, memberikan informasi, memberikan instruksi untuk menarik siswa agar bertindak dalam suatu aktivitas.

Brown (1983:17) menyatakan bahwa "educational media of all types incresaingly important roles in enabling students to reap benefits from individualized learning", semua jenis media pembelajaran akan terus meningkatkan peran untuk memungkinkan siswa memperoleh manfaat dari pembelajaran yang berbeda. Menggunakan media pembelajarn secara efektif, akan menciptakan suatu proses belajar mengajar yang optimal. Pernyataan tersebut dapat disimpulkan bahwa media pembelajaran merupakan salah satu bagian penting dari proses pembelajaran.

Media pembelajaran memberikan manfaat dari pendidik maupun peserta didik. Arsyad (2002 : 26) mengemukakan manfaat media media pengajaran dalam proses belajar mengajar sebagai berikut. 1) Media pengajaran dapat memperjelas penyajian pesan dan informasi sehingga dapat memperlancar dan meningkatkan proses dan hasil belajar. 2) Media pengajaran dapat meningkatkan dan mengarahkan perhatian anak sehingga dapat menimbulkan motivasi belajar, interaksi yang lebih langsung antara siswa dengan lingkungannya, dan memungkinkan siswa untuk belajar sendiri-sendiri sesuai dengan kemampuan dan minatnya. 3) Media pengajaran dapat mengatasi keterbatasan indera, ruang, dan 
waktu. 4) Media pengajaran dapat memberikan kesamaan pengalaman kepada siswa tentang peristiwa-peristiwa di lingkungan mereka, serta memungkinkan terjadinyya interaksi langsung dengan guru, masyarakat, dan lingkungan. Pendapat Arsyad tentang manfaat media pembelajaran di atas dapat disimpulkan bahwa media pembelajaran dapat membantu proses belajar mengajar.

Media Pembelajaran menurut taksonomi Leshin, dkk (dalam Arsyad, 2002: 79-101) adalah sebagai berikut, a) Media berbasis manusia. Media berbasis manusia merupakan media yang digunakan untuk mengirim dan mengkomunikasikan peran atau informasi b) Media berbasis cetakan. Media pembelajaran berbasis cetakan yang paling umum dikenal adalah buku teks, buku penuntun, buku kerja atau latihan, jurnal, majalah, dan lembar lepas. c) Media berbasis visual. Media berbasis visual (image) dalam hal ini memegang peranan yang sangat penting dalam proses belajar. Media visual dapat memperlancar pemahaman dan memperkuat ingatan. Visual dapat pula menumbuhkan minat siswa dan dapat memberikan hubungan antara isi materi pelajaran dengan dunia nyata. d) Media berbasis audiovisual. Media visual yang menggabungkan penggunaan suara memerlukan pekerjaan tambahan untuk memproduksinya. Salah satu pekerjaan penting yang diperlukan dalam media audio-visual adalah penulisan naskah dan storyboadr yang memerlukan persiapan yang banyak, rancangan dan penelitian. e) Media berbasis komputer. Komputer memilih fungsi yang berbeda-beda dalam bidang pendidikan dan latihan komputer berperan sebagai manajer dalam proses pembelajaran yang dikenal dengan nama Computer Managed Instruction (CMI). Modus ini dikenal sebagai Computer Assisted Instruction (CAI). CAI mendukung pembelajaran dan pelatihan, akan tetapi ia bukanlah penyampai utama materi pelajaran.

Jenis-jenis media menurut Bretz (dalam Widyastuti dan Nurhidayati, 2010: 17-18) mengklasifikasikan media ke dalam tujuh kelompok yaitu: (1) Media audio, seperti: siaran berita bahasa Jawa dalam radio, sandiwara bahasa Jawa dalam radio, tape recorder beserta pita audio berbahasa Jawa. (2) Media cetak, seperti: buku, modul, bahan ajar mandiri (3) Media visual diam, seperti: foto, slide, gambar (4) Media visual gerak, seperti: film bisu, movie maker tanpa suara, video tanpasuara (5) Media audio semi gerak, seperti: tulisan jauh bersuara (6) Media audio visual diam, seperti: film rangkai suara, slide rangkai suara (7) Media audio visual gerak, seperti: film dokumenter tentang kesenian Jawa atau seni pertunjukan tradisional, video kethoprak, video wayang, video campursari. Henich (dalam Widyastuti dan Nurhidayati, 2010: 19) mengklasifikasikan media secara lebih sederhana, yaitu: (1) media yang tidak diproyeksikan, (2) media yang diproyeksikan, (3) media audio, (4) media video, (5) media berbasis komputer, (6) multimedia kit.

Menghasilkan suatu produk media pembelajaran yang baik maka diperlukan prinsip dalam pemilihan media. Setyosari (2008: 22) mengidentifikasi prinsip-prinsip media sebagai berikut: (1) identifikasi ciri-ciri media yang diperhatikan sesuai dengan kondisi, unjuk kerja (performance) atau tingkat setiap tujuan pembelajaran, (2) identifikasi kerakteristik siswa (pembelajar) yang memerlukan media pembelajaran khusus, (3) identifikasi karakteristik lingkungan belajar berkenaan dengan media pembelajar yang akan digunakan, (4) identifikasi pertimbangan praktis yang memungkinkan media mana yang mudah dilaksanakan, (5) identifikasi faktor ekonomi dan organisasi yang menentukan kemudahan penggunaan media pembelajaran. Menggunakan media harus memperhatikan prinsip pemilihan media terlebih dahulu.

Prinsip-prinsip dalam pemilihan media pembelajaran menurut Saud (2009: 97) adalah sebagai berikut: a) tepat guna, artinya media pembelajaran yang digunakan sesuai dengan kompetensi dasar, b) berdaya guna, artinya media pembelajaran yang digunakan mampu meningkatkan motivasi siswa, c) bervariasi, artinya media pembelajaran yang digunakan mampu mendorong sikap aktif siswa dalam belajar. Prinsip-prinsip media yang dipaparkan oleh Saud tersebut mengidentifikasikan bahwa media yang tepat guna, berdaya guna, dan bervariasi dapat menjadi suatu media pembelajaran yang baik. Isi media yang dirancang sesuai dengan desain pembelajaran dapat menjadikan media berkualitas. Media yang berkualitas akan menumbuhkan ketertarikan bagi peserta didik untuk belajar menggunakan media.

Pada umumnya, tahap pertama dalam desain pembelajaran adalah analisis untuk mengetahui kebutuhan dalam pembelajaran, dan mengidentifikasi masalah-masalah apa 
yang akan dipecahkan. Model Dick, Carey, dan Carey menerapkan tahapan ini, dengan demikian pengembangan yang dilakukan berbasis kebutuhan dan pemecahan masalah. Produk yang direkomendasikan dalam model ini yaitu sebuah produk yang dapat digunakan untuk belajar mandiri (Nasution, 1995; Dick, Carey, dan Carey, (2005); Heinich, Molenda, Russel, \& Smadino, 2002). Model ini juga memungkinkan warga belajar menjadi aktif berinteraksi karena menetapkan strategi dan tipe pembelajaran yang berbasis lingkungan. Dengan bentuk pembelajaran yang berbasis lingkungan, yang disesuaikan dengan konteks dan setting lingkungan sekitar atau disebut juga sebagai situational approach oleh Canale \& Swain (1980) memungkinkan pebelajar bahasa (sebagaimana dinyatkan oleh Sadtono, 1987) dapat mengoptimalkan kompetensi komunikatif.

$$
\text { Wirawan Istiono (2006:13), }
$$

Macriomedia Flash adalah suatu program aplikasi berbasis vektor standar authoring tool professional yang digunakan untuk membuat animasi dan bitmap yang sangat menarik untuk membuat animasi logo, movie, game, menu interaktis, dan pembuatan aplikasi-aplikasi web. Sedangkan Madcom (2004:12), Macromedia Flash adalah program grafis yang diperuntukkan untuk motion atau gerak dan dilengkapi dengan script untuk programming (action script), program ini memungkinkan pembuatan animasi media interaktif, game. Arno Prasetio (2006: 9) juga mengemukakan bahwa Macromedia Flash adalah suatu suatu software animasi yang dapat digunakan untuk mempermudah penyampaian suatu konsep yang bersifat abstrak yang dalam penerapannya menggunakan komputer dan media imager proyector.

Rumusan masalah penelitian ini adalah: (1) Apakah media pembelajaran bahasa Indonesia berbasis Macromedia Flash Professional 8 lebih layak digunakan sebagai media pembelajaran dalam rangka mencapai unsur daya guna, hasil guna dan daya tarik siswa dibandingkan media pembelajaran buku teks (catatan)?; (2) Apakah hasil belajar bahasa Indonesia dengan menggunakan media pembelajaran berbasis Macromedia Flash Professional 8 lebih tinggi dibandingkan dengan media pembelajaran buku teks (catatan) pada materi menulis surat.

\section{METODE}

Penelitian ini dilaksanakan di Sekolah Dasar Swasta Namira Jalan Setiabudi Pasar 1 No. 76 Tanjung Sari Medan, Kelas V. Perlakuan (eksperimen) dilaksanakan selama 2 kali pertemuan dengan alokasi waktu 2 x 35 menit tiap pertemuan. Proses pembelajaran dilakukan di dalam kelas. Dalam penelitian dan pengembangan ini, model yang dikembangkan mengacu kepada Research and Development (R\&D) dari model Borg and Gall (1983).

Kegiatan yang dilakukan adalah sebagai berikut:

1. Rancangan uji coba.

Uji coba ini akan dilakukan dalam beberapa tahapan yaitu:

a. Validasi ahli materi, validasi ahli media, validasi ahli desain

b. Analisis konseptual

c. Revisi produk tahap I, berdasarkan penilaian dan masukan dari ahli untuk perbaikan

d. Uji coba terhadap siswa perorangan (face to face) sebanyak 3 orang dan uji kelompok kecil sebanyak 9 siswa berdasarkan penilaian anget

e. Analisis konseptual dan produk

f. Revisi produk tahap II

g. Uji coba lapangan terhadap mahasiswa

h. Penilaian mengenai daya tarik dan kelayakan produk

i. Analisis empirik tahap III

j. Revisi kecil

k. Uji efektifitas produk

2. Subyek uji coba.

Subyek uji coba dalam penelitian dan pengembangan ini ahli materi, ahli desain dan media, dan siswa SD Namira Kelas V TA. 2014/2015. Uji coba perorangan (face to face) akan diambil sampel 3 siswa (pintar, sedang, kurang) untuk melihat tingkat keterbacaan apakah menarik atau tidak, uji kelompok berjumlah 9 orang, dan uji coba lapangan, sampel diambil pada satu kelas $( \pm 25$ siswa).

3. Pelaksanaan Uji Coba

Uji coba produk dalam pengembangan ini dilaksanakan dengan melalui beberapa langkah sebagai berikut:

a. Langkah pertama, menentukan sasaran uji coba yaitu ahli media, ahli desain, dan ahli materi serta siswa. Masukan dari masingmasing ahli adalah kesesuaian uraian materi dengan kompetensi inti dan kompetensi 
dasar, keakuratan materi, dan materi pendukung pembelajaran. Kemudian menganalisis konseptual serta revisi pengembangan revisi produk tahap I

b. Langkah kedua menetapkan subjek uji coba yang didasarkan pada kriteria pendidikan, keahlian, juga ketersediaan waktu dan tenaga untuk memberikan data yang diperlukan

c. Langkah ketiga pelaksana tinjauan ahli sebelum uji coba perorangan dan lapangan, terlebih dahulu produk diberikan kepada ahli untuk mendapatkan saran dan masukan sesuai dengan keahliannya masing-masing

d. Langkah keempat uji coba perorangan (uji satu-satu)

e. Langkah kelima uji coba kelompok kecil untuk mengetahui apakah masih ada kekurangan yang perlu diperbaiki untuk kemudian di revisi yang ke III

f. Langkah keenam uji coba lapangan untuk mengetahui apakah masih terdapat kekurangan-kekurangan yang perlu diperbaiki dari produk yang dikembangkan setelah diskusi baik berdasarkan tinjauan ahli maupun pada uji coba satu-satu dan kuji coba kelompok kecil. Jika masih terdapat kekurangan, maka dilakukan revisi ke IV. Jika tidak, maka produk dapat dinyatakan layak sebagai sumber belajar sahih di lapangan.

Dalam penelitian ini digunakan tiga jenis teknik pengumpulan data, yaitu (1) tes untuk menjaring data hasil belajar menulis surat, (2) lembar pengamatan untuk menjaring hasil praktek menulis surat, (3) lembar angket untuk memperoleh hasil data dari ahli materi, ahli desain pembelajaran, ahli media berbasis macromedia flash, siswa kelas V SD Namira.

Alat pengumpulan data yang digunakan untuk tes hasil belajar ini, yaitu: tes essay praktik yang berjumlah 8 soal untuk mengembangkan keterampilan psikomotorik siswa. Tes hasil belajar yang diberikan kepada responden untuk mengambil data penelitian ini berasal dari buku pegangan Bahasa Indonesia untuk Kleas V SD yang telah teruji validitas dan reabilitas tesnya. Maka dalam penelitian ini tidak dilakukan uji coba instrument untuk mengetahui tingkat validitas dan reabilitas tes tersebut.

$$
\frac{\text { Jumlah skor yang diperoleh }}{\text { Jumlah skor ideal seluruh item }} \times
$$

$100 \%$ Dalam penelitian ini data yang diperoleh adalah hasil belajar siswa dari kelas eksperimen dan kelas control. Teknik analisis data yang digunakan adalah teknik deskriptif kuantitatif dimana semua data yang terkumpul dianalisis dengan teknik statistik deskriptif yang secara kuantitatif dipisahkan menurut kategori untuk mempertajam penilaian dalam menarik kesimpulan. Data kualitatif yang berupa pernyataan sangat kurang, baik, cukup, sedang, dan sangat baik diubah menjadi data kuantitatif dengan skala 1 sampai dengan 5. Hasilnya dirata-rata dan digunakan untuk menilai kualitas media pembelajaran. Kriteria media pembelajaran akan dikonversikan menjadi nilai dengan skala lima menggunakan skala Likerts dinamis secara deskriptif persentase dengan rumusan sebagai berikut, (Sugiyono: 2007): X $=$

Teknik analisis data yang digunakan teknik analisis isi media pembelajaran berbasis macromedia flash, teknik analisis deskriptif dan teknik analisis uji t. Teknik deskriptif untuk menganalisis data dengan cara menggambar data yang telah terkumpul sebagaimana adanya tanpa bermaksud membuat kesimpulan yang berlaku umum atau generalisasi. Teknik inferensial untuk menganlisis data sampel sampel dan hasilnya diberlakukan untuk populasi.

Hipotesis :

Ho $: \mu \mathrm{A} 1 \leq \mu \mathrm{A} 2$

$\mathrm{Ha} \quad: \mu \mathrm{A} 1>\mu \mathrm{A} 2$

$\mu \mathrm{A} 1 \quad$ : Rata-rata hasil belajar siswa dengan media pembelajaran bahasa

Indonesia berbasis Macromedia Flash Professional

$\mu \mathrm{A} 2$ : Rata-rata hasil belajar siswa tanpa media pembelajaran bahasa

Indonesia berbasis Macromedia Flash Professional

\section{HASIL DAN PEMBAHASAN \\ Hasil}

Tabel 1. Skor Penilaian Media Pembelajaran Interaktif Berbasis Macromedia Flash Professional 8 oleh Ahli Materi Tentang Kualitas Materi Pembelajaran (Skala 1-5)

\begin{tabular}{|l|l|c|c|c|c|c|}
\hline \multirow{2}{*}{ No } & \multirow{2}{*}{ Indikator Penilaian } & \multicolumn{2}{|c|}{ Responden } & Rata- & \multirow{2}{*}{ Persentase } & \multirow{2}{*}{ Kriteria } \\
\cline { 3 - 4 } & & 1 & 2 & rata & \\
\hline
\end{tabular}




\begin{tabular}{|l|l|c|c|c|c|c|}
1 & Kebenaran dan Ketepatan Materi & 4 & 4 & 4 & $80,00 \%$ & Sangat Baik \\
\hline 2 & Ketepatan cakupan materi & 4 & 5 & 4,5 & $90,00 \%$ & Sangat Baik \\
\hline 3 & Kebenaran konsep pembelajaran & 4 & 4 & 4 & $80,00 \%$ & Sangat Baik \\
\hline 4 & Kedalaman materi dengan kurikulum & 4 & 4 & 4 & $80,00 \%$ & Sangat Baik \\
\hline 5 & Kesusaian dengan & 4 & $80,00 \%$ & Sangat Baik \\
\hline 6 & Ketepatan urutan materi pembelajaran & 3 & 4 & 3,5 & $70,00 \%$ & Baik \\
\hline \multicolumn{2}{|c|}{ Penilaian secara keseluruhan } & 4 & 4,5 & 4 & $85,00 \%$ & Sangat Baik \\
\hline
\end{tabular}

Tabel 2. Skor Penilaian Media Pembelajaran Interaktif Berbasis Macromedia Flash Professional 8 oleh Ahli Materi Tentang Kualitas Strategi Pembelajaran (Skala 1-5)

\begin{tabular}{|c|c|c|c|c|c|c|}
\hline \multirow{2}{*}{ No } & \multirow{2}{*}{ Indikator Penilaian } & \multicolumn{2}{|c|}{ Responden } & \multirow{2}{*}{$\begin{array}{l}\text { Rata- } \\
\text { rata }\end{array}$} & \multirow{2}{*}{ Persentase } & \multirow{2}{*}{ Kriteria } \\
\hline & & 1 & 2 & & & \\
\hline 1 & Kualitas Pendahuluan & 4 & 5 & 4,5 & $90,00 \%$ & Sangat Baik \\
\hline 2 & Kualitas Penyajian Materi & 4 & 4 & 4 & $80,00 \%$ & Sangat Baik \\
\hline 3 & $\begin{array}{l}\text { Keterlibatan dan peran siswa dalam } \\
\text { aktivitas belajar }\end{array}$ & 3 & 3 & 3 & $60,00 \%$ & Baik \\
\hline 4 & Kualitas umpan balik & 4 & 4 & 4 & $80,00 \%$ & Sangat Baik \\
\hline 5 & Waktu penyajian & 4 & 4 & 4 & $80,00 \%$ & Sangat Baik \\
\hline & Penilaian secara keseluruhan & 4 & 4,4 & 3,9 & $84,00 \%$ & Sangat Baik \\
\hline
\end{tabular}

Tabel 3. Skor Penilaian Media Pembelajaran Interaktif Berbasis Macromedia Flash Professional 8 oleh Ahli Materi Tentang Sistem Penyampaian Pembelajaran (Skala 1-5)

\begin{tabular}{|c|l|c|c|c|c|c|}
\hline \multirow{2}{*}{ No } & \multirow{2}{*}{ Indikator Penilaian } & \multicolumn{2}{|c|}{ Responden } & \multirow{2}{*}{$\begin{array}{c}\text { Rata- } \\
\text { rata }\end{array}$} & \multirow{2}{*}{ Persentase } & \multirow{2}{*}{ Kriteria } \\
\cline { 3 - 5 } & & 1 & 2 & & \\
\hline 1 & Penggunaan Bahasa & 4 & 5 & 4,5 & $90,00 \%$ & Sangat Baik \\
\hline 2 & Kemudahan Pemahaman bahasa & 4 & 4 & 4 & $80,00 \%$ & Sangat Baik \\
\hline 3 & Perwajahan/tampilan & 5 & 5 & 5 & $100,00 \%$ & Sangat Baik \\
\hline 4 & Ilustrasi & 4 & 4 & 4 & $80,00 \%$ & Sangat Baik \\
\hline \multicolumn{2}{|l|}{ Penilaian secara keseluruhan } & 4,5 & 5 & 4,38 & $95,00 \%$ & Sangat Baik \\
\hline
\end{tabular}

Hasil validasi berupa skor penilaian komponen media pembelajaran berbasis Macromedia Flash Professional 8

Tabel 4. Skor Penilaian Media Pembelajaran Berbasis Macromedia Flash Professional 8 oleh Ahli Desain Tentang Aspek Kualitas Pembelajaran (Skala 1-5)

\begin{tabular}{|c|c|c|c|c|c|c|}
\hline \multirow{2}{*}{ No } & \multirow{2}{*}{ Indikator Penilaian } & \multicolumn{2}{|c|}{ Responden } & \multirow{2}{*}{$\begin{array}{l}\text { Rata- } \\
\text { rata }\end{array}$} & \multirow{2}{*}{ Persentase } & \multirow{2}{*}{ Kriteria } \\
\hline & & 1 & 2 & & & \\
\hline 1 & Ketepatan Pemilihan Topik & 5 & 4 & 4.5 & $90.00 \%$ & Sangat Baik \\
\hline 2 & $\begin{array}{l}\text { Kesesuaian materi dengan } \\
\text { indikator pembelajaran }\end{array}$ & 4 & 4 & 4 & $80.00 \%$ & Sangat Baik \\
\hline 3 & Pemberian latihan & 4 & 4 & 4 & $80.00 \%$ & Sangat Baik \\
\hline 4 & $\begin{array}{l}\text { Konsistensi tes dengan } \\
\text { indikator pembelajaran }\end{array}$ & 5 & 4 & 4.5 & $90.00 \%$ & Sangat Baik \\
\hline & Penilaian secara keseluruhan & 4.75 & 4.5 & 4.25 & $92.50 \%$ & Sangat Baik \\
\hline
\end{tabular}

Tabel 5. Skor Penilaian Media Pembelajaran Berbasis Macromedia Flash Professional 8 oleh Ahli Desain Tentang Desain Informasi (Skala 1-5)

\begin{tabular}{|c|l|c|c|c|c|c|}
\hline \multirow{2}{*}{ No } & \multirow{2}{*}{ Indikator Penilaian } & \multicolumn{2}{|c|}{ Responden } & Rata- & \multirow{2}{*}{ Persentase } & \multirow{2}{*}{ Kriteria } \\
\cline { 3 - 5 } & & $\mathbf{1}$ & $\mathbf{2}$ & rata & & \\
\hline 1 & Pemberian Motivasi & 4 & 4 & 4 & $80.00 \%$ & Sangat Baik \\
\hline
\end{tabular}




\begin{tabular}{|c|l|c|c|c|c|c|}
2 & Kejelasan uraian materi & 4 & 4 & 4 & $80.00 \%$ & Sangat Baik \\
\hline 3 & Kejelasan contoh yang diberikan & 4 & 4 & 4 & $80.00 \%$ & Sangat Baik \\
\hline 4 & Penggunaan informasi baru & 4 & 3 & 3.5 & $70.00 \%$ & Baik \\
\hline 5 & $\begin{array}{l}\text { Umpan balik terhadap hasil tes } \\
\text { siswa }\end{array}$ & 4 & 4 & 4 & $80.00 \%$ & Sangat Baik \\
\hline 6 & Pembabakan/sekuensial & 4 & 4 & 4 & $80.00 \%$ & Sangat Baik \\
\hline 7 & $\begin{array}{l}\text { Pemaksimalan proses } \\
\text { pembelajaran }\end{array}$ & 4 & 3 & 3.5 & $70.00 \%$ & Baik \\
\hline & Penilaian secara keseluruhan & 4.14 & 4 & 3.86 & $81,43 \%$ & Sangat Baik \\
\hline
\end{tabular}

Tabel 6. Skor Penilaian Media Pembelajaran Berbasis Macromedia Flash Professional 8 oleh Ahli Desain Tentang Desain Interaksi (Skala 1-5)

\begin{tabular}{|c|c|c|c|c|c|c|}
\hline \multirow{2}{*}{ No } & \multirow{2}{*}{ Indikator Penilaian } & \multicolumn{2}{|c|}{ Responden } & \multirow{2}{*}{$\begin{array}{l}\text { Rata- } \\
\text { rata }\end{array}$} & \multirow{2}{*}{ Persentase } & \multirow{2}{*}{ Kriteria } \\
\hline & & 1 & 2 & & & \\
\hline 1 & Penggunaan petunjuk belajar & 5 & 4 & 4.5 & $90.00 \%$ & Sangat Baik \\
\hline 2 & Penjelasan Istilah & 5 & 3 & 4 & $80.00 \%$ & Sangat Baik \\
\hline 3 & $\begin{array}{l}\text { Umpan balik terhadap respon } \\
\text { siswa }\end{array}$ & 4 & 4 & 4 & $80.00 \%$ & Sangat Baik \\
\hline 4 & $\begin{array}{l}\text { Penggunaan teks yang berbeda } \\
\text { untuk menandai bagian yang } \\
\text { penting }\end{array}$ & 5 & 3 & 4 & $80.00 \%$ & Sangat Baik \\
\hline & Penilaian secara keseluruhan & 5 & 4 & 4.13 & $90,00 \%$ & Sangat Baik \\
\hline
\end{tabular}

Tabel 7. Skor Penilaian Media Pembelajaran Berbasis Macromedia Flash Professional 8 oleh Ahli Desain Tentang Aspek Kualitas Persentasi (Skala 1-5)

\begin{tabular}{|c|c|c|c|c|c|c|}
\hline \multirow{2}{*}{ No } & \multirow{2}{*}{ Indikator Penilaian } & \multicolumn{2}{|c|}{ Responden } & \multirow{2}{*}{$\begin{array}{l}\text { Rata- } \\
\text { rata }\end{array}$} & \multirow{2}{*}{ Persentase } & \multirow{2}{*}{ Kriteria } \\
\hline & & $\mathbf{1}$ & 2 & & & \\
\hline 1 & Komposisi warna & 4 & 4 & 4 & $80.00 \%$ & Sangat Baik \\
\hline 2 & Penggunaan grafis & 4 & 4 & 4 & $80.00 \%$ & Sangat Baik \\
\hline 3 & Pemilihan jenis dan ukuran font & 4 & 4 & 4 & $80.00 \%$ & Sangat Baik \\
\hline 4 & Penggunaan tombol navigasi & 4 & 4 & 4 & $80.00 \%$ & Sangat Baik \\
\hline 5 & Kualitas gambar dan animasi & 4 & 5 & 4.5 & $90.00 \%$ & Sangat Baik \\
\hline 6 & Penggunaan musik & 4 & 3 & 3.5 & $70.00 \%$ & Baik \\
\hline 7 & Kemudahan penggunaan & 5 & 5 & 5 & $100.00 \%$ & Sangat Baik \\
\hline & Penilaian secara keseluruhan & 4.29 & 4.4286 & 4.14 & $87,14 \%$ & Sangat Baik \\
\hline
\end{tabular}

Hasil validasi berupa skor penilaian komponen media pembelajaran berbasis Macromedia Flash Professional 8

Tabel. Skor Penilaian Media Pembelajaran Berbasis Macromedia Flash Professional 8 oleh Ahli Media dan Desain Grafis Tentang Pemograman (Skala 1-5)

\begin{tabular}{|c|c|c|c|c|c|c|}
\hline \multirow{2}{*}{ No } & \multirow{2}{*}{ Indikator Penilaian } & \multicolumn{2}{|c|}{ Responden } & \multirow{2}{*}{$\begin{array}{c}\text { Rata- } \\
\text { rata }\end{array}$} & \multirow{2}{*}{ Persentase } & \multirow{2}{*}{ Kriteria } \\
\hline & & 1 & 2 & & & \\
\hline 1 & Perintah eksekusi & 4 & 5 & 4.5 & $90.00 \%$ & Sangat Baik \\
\hline 2 & $\begin{array}{l}\text { Konsistensi dengan alur } \\
\text { program }\end{array}$ & 5 & 4 & 4.5 & $90.00 \%$ & Sangat Baik \\
\hline 3 & Keberlanjutan Program & 4 & 4 & 4 & $80.00 \%$ & Sangat Baik \\
\hline 4 & Efisiensi Sistem & 4 & 5 & 4.5 & $90.00 \%$ & Sangat Baik \\
\hline 5 & Ketepatan Display & 4 & 4 & 4 & $80.00 \%$ & Sangat Baik \\
\hline 6 & Pengelolaan disc & 4 & 4 & 4 & $80.00 \%$ & Sangat Baik \\
\hline
\end{tabular}




\begin{tabular}{|c|l|c|c|c|c|c|}
7 & $\begin{array}{l}\text { Konsistensi antar bagian } \\
\text { pelajaran }\end{array}$ & 5 & 5 & 5 & $100.00 \%$ & Sangat Baik \\
\hline 8 & Modifikasi yang mudah & 5 & 4 & 4.5 & $90.00 \%$ & Sangat Baik \\
\hline Penilaian secara keseluruhan & 4.50 & 4.63 & 4.38 & $91.25 \%$ & Sangat Baik \\
\hline
\end{tabular}

Tabel 9. Skor Penilaian Media Pembelajaran Berbasis Macromedia Flash 8 Menulis Surat Tentang Kualitas Materi Pembelajaran

\begin{tabular}{|c|c|c|c|c|c|c|c|c|}
\hline \multirow{2}{*}{ No } & \multirow{2}{*}{ Indikator Penilaian } & \multicolumn{5}{|c|}{ Responden } & \multirow{2}{*}{ Persentase } & \multirow{2}{*}{ Kriteria } \\
\hline & & 1 & 2 & 3 & 4 & 5 & & \\
\hline 1 & Kesesuaian Materi & & & & 2 & 48 & $95.56 \%$ & Sangat Baik \\
\hline 2 & $\begin{array}{l}\text { Kejelasan Petunjuk } \\
\text { Belajar }\end{array}$ & & & & 5 & 45 & $88.89 \%$ & Sangat Baik \\
\hline 3 & $\begin{array}{l}\text { Kemudahan Memahami } \\
\text { Kalimat }\end{array}$ & & & & 8 & 42 & $82.22 \%$ & Sangat Baik \\
\hline 4 & $\begin{array}{l}\text { Kemudahan Memahami } \\
\text { Pembelajaran }\end{array}$ & & & & 3 & 47 & $93.33 \%$ & Sangat Baik \\
\hline 5 & $\begin{array}{l}\text { Ketepatan Urutan } \\
\text { Penyajian }\end{array}$ & & & & 8 & 42 & $82.22 \%$ & Sangat Baik \\
\hline 6 & Kecukupan Latihan & & & & 8 & 42 & $82.22 \%$ & Sangat Baik \\
\hline 7 & Kejelasan Umpan Balik & & & & 2 & 48 & $95.56 \%$ & Sangat Baik \\
\hline 8 & $\begin{array}{l}\text { Bantuan belajar dengan } \\
\text { program }\end{array}$ & & & & 2 & 48 & $95.56 \%$ & Sangat Baik \\
\hline \multicolumn{7}{|c|}{ Penilaian secara keseluruhan } & $89.44 \%$ & Sangat Baik \\
\hline
\end{tabular}

Tabel 10. Skor Penilaian Media Pembelajaran Berbasis Macromedia Flash 8 Menulis Surat Tentang Kualitas Teknis/Tampilan

\begin{tabular}{|c|c|c|c|c|c|c|c|c|}
\hline \multirow{2}{*}{ No } & \multirow{2}{*}{ Indikator Penilaian } & \multicolumn{5}{|c|}{ Responden } & \multirow{2}{*}{ Persentase } & \multirow{2}{*}{ Kriteria } \\
\hline & & 1 & 2 & 3 & 4 & 5 & & \\
\hline 1 & Keindahan Tampilan Layar & & & & 6 & 44 & $86.67 \%$ & Sangat Baik \\
\hline 2 & Keterbacaan teks & & & & 6 & 44 & $86.67 \%$ & Sangat Baik \\
\hline 3 & $\begin{array}{l}\text { Kualitas gambar dan } \\
\text { Animasi }\end{array}$ & & & & 8 & 42 & $82.22 \%$ & Sangat Baik \\
\hline 4 & Komposisi warna & & & & 3 & 47 & $93.33 \%$ & Sangat Baik \\
\hline 5 & Navigasi & & & & 1 & 49 & $97.78 \%$ & Sangat Baik \\
\hline 6 & Daya Dukung Musik & & & & 2 & 48 & $95.56 \%$ & Sangat Baik \\
\hline 7 & Interaksi & & & & 4 & 46 & $91.11 \%$ & Sangat Baik \\
\hline \multicolumn{7}{|c|}{ Penilaian secara keseluruhan } & $90.48 \%$ & Sangat Baik \\
\hline
\end{tabular}

Berdasarkan hasil penilaian pada media pembelajaran interaktif menulis surat pada uji lapangan tidak terdapat perbaikan. Persentase rata-rata dari hasil uji lapangan terlihat pada Tabel 11. di bawah ini

Tabel 11. Persentase Rata-rata Hasil Penilaian Terhadap Media Pembelajaran Berbasis Macromedia Flash 8 Menulis Surat Uji Lapangan

\begin{tabular}{|c|c|c|c|}
\hline \multirow{2}{*}{ No } & Kategorisasi & Persentase Rata-rata & Kriteria \\
\hline 1 & Aspek kualitas materi pembelajaran & $89.44 \%$ & Sangat Baik \\
\hline 2 & Aspek Kualitas teknis atau tampilan & $90.48 \%$ & Sangat Baik \\
\hline \multicolumn{2}{|c|}{ Rata-rata } & $89.96 \%$ & Sangat Baik \\
\hline
\end{tabular}


Uji $\mathrm{t}$ dilakukan untuk mengetahui apakah terdapat perbedaan kemampuan awal kelas kontrol dan eksperimen. Berdasarkan hasil perhitungan diperoleh $\mathrm{t}_{\mathrm{hit}}=0,40$, $\mathrm{t}_{\text {tabel }}$ $0,05(2,49)=1,67$ maka $_{\mathrm{h}}(0,40)<\mathrm{t}_{\mathrm{t}}(1,67)$ untuk taraf signifikansi $(\alpha=0,05)$ atau dengan kata lain Ha ditolak. Hal ini mengidinkasikan bahwa kemampuan awal siswa baik kelas kontrol ataupun kelas eksperimen adalah cenderung saama dan tidak berbeda.

Berdasarkan hasil perhitungan diperoleh $\mathrm{t}_{\text {hit }}=13,08, \mathrm{t}_{\text {tabel0,05(2,49) }}=1,67$ maka $\mathrm{t}_{\mathrm{h}}$ $(13,08)>t_{t}(1,67)$ untuk taraf signifikansi $(\alpha=0,05)$ atau dengan kata lain Ha diterima dan Ho ditolak, maka dapat disimpulkan bahwa hasil belajar bahasa Indonesia dengan materi menulis surat dengan menggunakan media pembelajaran bahasa Indonesia berbasis Macromedia Flash Professional 8 lebih tinggi daripada hasil belajar bahasa Indonesia dengan materi menulis surat tanpa menggunakan media pembelajaran bahasa Indonesia berbasis Macromedia Flash Professional 8.

Nilai keefektifan media pembelajaran bahasa Indonesia berbasis Macromedia Flash Professional 8 diperoleh sebagai berikut

$100 \%$

$$
\mathbf{X}=\frac{\text { Jumlah skor yang diperoleh }}{\text { Jumlah skor ideal seluruh item }} \times
$$

$$
X=\frac{2129}{2500} \times 100 \%=85,00 \%
$$

Nilai keefektifan tanpa media pembelajaran bahasa Indonesia berbasis Macromedia Flash Professional 8 diperoleh sebagai berikut

$$
X=\frac{1897}{2500} \times 100 \%=75,90 \%
$$

dengan efektifitas penggunaan media interaktif sebesar $85,00 \%$, dibandingkan dengan nilai keefektifan pembelajaran tanpa media yaitu $75,90 \%$. Jadi, dapat disimpulkan media pembelajaran bahasa Indonesia berbasis Macromedia Flash Professional 8 lebih efektif digunakan untuk meningkatkan hasil belajar bahasa Indonesia dengan materi menulis surat.

\section{Pembahasan}

Penelitian dan pengembangan produk ini menghasilkan suatu produk berupa media pembelajaran interaktif bahasa Indonesia berbasis Macromedia Flash Professional 8 dengan materi menulis surat. Media interaktif digunakan sebagai suatu strategi dalam meningkatkan hasil belajar bahasa Indonesia.

Untuk meningkatkan hasil belajar pengembangan media interaktif bahasa
Indonesia berbasis Macromedia Flash Professional 8 dengan materi menulis surat dilakukan beberapa tahapan yang dirujuk dari tahapan model pengembangan sistem pembelajaran (Instructional Systems Develovment / ISD) Dick, Carey, dan Carey (2001) berdasarkan 9 tahapan yaitu (1) analisis kebutuhan untuk menentukan tujuan. Tujuan pembelajaran dapat diperoleh dari serangkaian tujuan pembelajaran yang ditemukan dari analisis kebutuhan, dari kesulitan-kesulitan warga belajar dalam praktek pembelajaran, dari analisis yang dilakukan oleh orang-orang yang bekerja dalam bidang, atau beberapa keperluan untuk pembelajaran yang aktual, (2) melakukan analisis pembelajaran yaitu menentukan keterampilan, pengetahuan, dan sikap yang disebut sebagai entry behavior (perilaku awal/masukan) yang diperlukan oleh warga belajar untuk memulai pembelajaran, (3) menganalisis warga belajar dan lingkungannya, meliputi keterampilan-keterampilan warga belajar yang ada saat ini, yang lebih disukai, dan sikap-sikap ditentukan berdasarkan karakteristik atau setting pembelajaran dan setting lingkungan tempat keterampilan diterapkan. Langkah ini adalah langkah awal yang penting dalam strategi pembelajaran, (4) merumuskan tujuan khusus, dengan mengidentifikasi keterampilan-keterampilan yang dipelajari, kondisi pencapaian unjuk kerja, dan kriteria pencapaian unjuk kerja, (5) mengembangkan instrumen penilaian, dengan mengembangkan produk evaluasi untuk mengukur kemampuan warga belajar melakukan tujuan pembelajaran. Penekanan utama berada pada hubungan perilaku yang tergambar dalam tujuan pembelajaran dengan untuk apa melakukan penilaian, mengembangkan strategi pembelajaran, meliputi; kegiatan prapembelajaran (preactivity), penyajian informasi, praktek dan umpan balik (practice and feedback, pengetesan (testing), dan mengikuti kegiatan selanjutnya. Strategi pembelajaran berdasarkan teori dan hasil penelitian, karakteristik media pembelajaran yang digunakan, bahan pembelajaran, dan karakteristik warga belajar yang menerima pembelajaran, (7) mengembangkan materi pembelajaran, produk pengembangan ini meliputi petunjuk untuk warga belajar, materi pembelajaran, dan soalsoal. Pengembangan materi pembelajaran tergantung kepada tipe pembelajaran, materi yang relevan, dan sumber belajar yang ada 
disekitar perancang, (8) merancang \& mengembangkan evaluasi formatif, dan (9) merevisi pembelajaran, data yang diperoleh dari evaluasi formatif dikumpulkan dan diinterpretasikan untuk memecahkan kesulitan yang dihadapi warga belajar dalam mencapai tujuan. Bukan hanya untuk ini, singkatnya hasil evaluasi ini digunakan untuk merevisi pembelajaran agar lebih efektif. Tahapantahapan ini digunakan dalam proses pembelajaran sehingga dihasilkan media pembelajaran yang layak digunakan sesuai dengan karakteristik siswa dan bidang studi.

Menurut Latuheru (1988: 23), manfaat media pembelajaran yaitu: 1) media pembelajaran menarik dan memperbesar perhatian anak-anak didik terhadap materi pengajaran yang disajikan, 2) media pembelajaran mengurangi, bahkan dapat menghilangkan adanya verbalisme, 3) media pembelajaran mengatasi perbedaan pengalaman belajar berdasarkan latar belakang sosial ekonomi dari anak didik, 4) media pembelajaran membantu memberikan pengalaman belajar yang sulit diperoleh dengan cara yang lain, 5) media pembelajaran dapat mengatasi masalah batas-batas ruang dan waktu, 6) media pembelajaran dapat membantu perkembangan pikiran anak didik secara teratur tentang hal yang mereka alami, 7) media pembelajaran dapat membantu anak didik dalam mengatasi hal yang sulit nampak dengan mata, 8) media pembelajaran dapat menumbuhkan kemampuan berusaha sendiri berdasarkan pengalaman dan kenyataan, 9) media pembelajaran dapat mengatasi hal/peristiwa/kejadian yang sulit diikuti oleh indera mata, 10) media pembelajaran memungkinkan terjadinya kontak langsung antara anak didik, guru, dengan masyarakat, maupun dengan lingkungan alam di sekitar mereka.

Hardiyanto, (2011) dalam penelitian menunjukkan bahwa dengan pemanfaatan media pembelajaran bahasa Indonesia berbasis Macromedia Flash Professional 8 sebagai media pembelajaran, dapat meningkatkan motivasi belajar siswa dari $49,56 \%$ menjadi $67,33 \%$. Pengembangan desain pembelajaran digunakan sebagai pedoman dalam penyelenggaraan agar tercapai pembelajaran yang efektif, efisien dan berdaya guna. Macromedia Flash sering digunakan animator untuk membuat animasi interaktif maupun non interaktif, seperti animasi pada halaman web dan animasi kartun. Software ini mempunyai banyak keunggulan dibandingkan dengan software animasi lainnya diantaranya adalah program yang berorientasi objek, mampu mendesain gambar berbasis vector, kemampuannya menghasilkan animasi gerak dan suara.

Media pembelajaran khususnya untuk menarik minat belajar siswa dan menghilangkan kejenuhan siswaa dalam mengikuti pembelajaran pelajaran bahasa Indonesia pada materi menulis surat serta arus globalisasi teknologi dan informasi yang semakin maju perkembangannya. Media pembelajaran berbasis Macromedia Flash mata pelajaran bahasa Indonesia dipilih sebagai metode alternatif dalam pengembangan media pembelajaran, sehingga dengan adanya media tersebut maka hasil belajar siswa akan lebih tinggi dibandingkan dengan hasil belajar siswa yang diajarkan dengan cara konvensional.

Multimedia pembelajaran yang dikembangkan dikemas dalam bentuk kepingan compact disk (CD) dengan menggunakan Macromedia Flash Professional 8 sebagai software utama dan program-program lain yang diperlukan pendukung. Serta dapat disimpan di hard disk computer dan flashdisk.

Penggunaan multimedia pembelajaran ini memungkinkan peserta didik lebih mudah dalam belajar bahasa Indonesia karena dilengkapi dengan warna, musik, film dan animasi, serta memuat standar kompetensi, kompetensi dasar, dan indikator. Siswa dapat berinteraksi langsung dengan media pembelajaran, siswa juga dapat mengulangulang materi yang belum dipahaminya. Produk dapat digunakan secara fleksibel sesuai keinginan peserta didik dan dilengkapi latihan / evaluasi belajar. Media pembelajaran ini sangat praktis, karena dapat dibawa oleh siswa dan dapat dipelajari di rumah karena media pembelajaran initeraktif ini dalam bentuk flash. Media pembelajaran ini juga disertai dengan latihan-latihan berupa tes pilihan ganda yang memiliki durasi waktu dan kunci jawaban yang benar, sehingga siswa dapat mengetahui kesalahan yang telah dilakukan dalam mengerjakan soal latihan tersebut. Tanpa media pembelajaran proses belajar cenderung membosankan, karena pembelajaran menjadi satu arah guru aktif dan murid pasif menerima dan mengikuti apa yang disampaikan guru.

Media pembelajaran ini menggunakan teks, gambar, animasi, paduan warna sesuai 
keperluan, sehingga dapat memudahkan pemahaman, menarik perhatian, dan menyenangkan. Multimedia pembelajaran ini dapat digunakan untuk individu secara mandiri, maupun klasikal sesuai ketersediaan jumlah komputer. Atau juga bisa digunakan dengan bantuan fasilitas liquid crystal display (LCD) proyektor. Media pembelajaran ini sangat efektif digunakan untuk meningkatkan hasil belajar Bahasa Indonesia.

\section{PENUTUP}

Media pembelajaran berbasis Macromedia Flash Professional 8 lebih layak daripada media pembelajaran buku teks (catatan) untuk digunakan pada pembelajaran bahasa Indonesia dengan materi menulis surat yang dapat disebarluarkan dan diimplemantasikan kepada para pengguna. Hal ini diperjelas dengan beberapa tahapan uji coba, baik uji coba dari ahli materi, uji coba ahli desain pembelajaran, uji coba ahli media/desain grafis, uji coba perorangan, uji coba kelompok dan uji coba lapangan dengan rata-rata kategori 'sangat baik'.

Hasil belajar bahasa Indonesia yang diajarkan dengan media pembelajaran berbasis Macromedia Flash Professional 8 lebih tinggi daripada hasil belajar yang diajarkan dengan media pembelajaran buku teks (catatan) pada materi menulis surat. Dengan demikian, media pembelajaran bahasa Indonesia berbasis Macromedia Flash Professional 8 lebih efektif digunakan untuk meningkatkan hasil belajar bahasa Indonesia dengan materi menulis surat.

\section{DAFTAR PUSTAKA}

Arsyad, Azhar. 1997. Media Pengajaran. Jakarta: Raja Grafindo Persada

Bruner, J. S. 1960. The Process of Education. New York: Vintage Book

Dahar, R. W. 1989. Teori-Teori Belajar. Jakarta: Erlangga
Depdiknas. 2003. Hasil Belajar. http://www.geocities.com

Dick, W, Carey, L. 2005. The systemic design of Instruction. United States of America: Scott Foresman and Company

Hamalik. 1994. Media Pendidikan. Bandung: Citra Aditya Bakti

Latuheru, JD. 1988. Media Pembelajaran dalam Proses Belajar Masa Kini. Jakarta: Depdikbud Marson

Romiszowski. 1988. The Selection and Use of Instructional Media. United States: Nicholas Publishing

Sadiman, Arif, dkk. 1984. Media Pendidikan, Pengertian, Pengembangan dan Pemanfaatannya. Jakarta: Putekkom Dikbud

Sadiman, Arif. 1993. Media Pendidikan. Jakarta: Raja Grafindo Persada

Sudjana, Nana. 2004. Penilaian Hasil Proses Belajar Mengajar. Bandung: Rosdakarya

Sudjana, 2001. Media Pengajaran. Bandung: Sinar baru Algesindo

Sudjana, Nana. 2002. Dasar-Dasar proses Belajar Mengajar. Bandung: Sinar Baru Algesindo

Syah, Muhibbin. 1996. Psikologi Pendidikan dengan Pendekatan Baru. Bandung: Remaja Rosdakarya

Tarigan, H.G. 1982. Menulis sebagai Keterampilan Berbahasa. Bandung: Angkasa

Tarigan, H. G. 1979. Pengajaran Analisis Kesalahan Berbahasa. Bandung: Angkasa

Widyastuti, S. H dan Nurhidayati. 2010. Pengembangan Media Pembelajaran Bahasa Jawa. Diktat Mata Kuliah Media Pembelajaran. Yogyakarta: Universitas Negeri Yogyakarta

W. S, Winkel. 2004. Bimbingan dan Konseling di Institusi Pendidikan. Yogyakarta: Media Abadi

W. S, Winkel. 2007. Psikologi Pengajaran. Jakarta: Gramedia 